\title{
Injuries caused by aquatic animals in Brazil: an analysis of the data present in the information system for notifiable diseases
}

\author{
Guilherme Carneiro Reckziegel[1], Flávio Santos Dourado ${ }^{[1]}$, \\ Domingos Garrone Neto ${ }^{[2]}$ and Vidal Haddad Junior ${ }^{[3]}$
}

[1]. Programa Nacional de Controle de Acidentes por Animais Peçonhentos, Coordenação-Geral de Doenças Transmissíveis, Ministério da Saúde, Brasília, Distrito Federal, Brasil. [2]. Curso de Graduação em Engenharia de Pesca, Universidade Estadual Paulista, Registro, São Paulo, Brasil. [3]. Faculdade de Medicina de Botucatu, Universidade Estadual Paulista, Botucatu, São Paulo, Brasil.

\begin{abstract}
Introduction: We present a review of injuries in humans caused by aquatic animals in Brazil using the Information System for Notifiable Diseases [Sistema de Informação de Agravos de Notificação (SINAN)] database. Methods: A descriptive and retrospective epidemiological study was conducted from 2007 to 2013. Results: A total of 4,118 accidents were recorded. Of these accidents, $88.7 \%(3,651)$ were caused by venomous species, and $11.3 \%(467)$ were caused by poisonous, traumatic or unidentified aquatic animals. Most of the events were injuries by stingrays $(69 \%)$ and jellyfish $(13.1 \%)$. The North region was responsible for the majority of reports (66.2\%), with a significant emphasis on accidents caused by freshwater stingrays (92.2\% or 2,317 cases). In the South region, the region with the second highest number of records $(15.7 \%)$, jellyfish caused the majority of accidents $(83.7 \%$ or 452 cases). The Northeastern region, with $12.5 \%$ of the records, was notable because almost all accidents were caused by toadfish $(95.6 \%$ or 174 cases). Conclusions: Although a comparison of different databases has not been performed, the data presented in this study, compared to local and regional surveys, raises the hypothesis of underreporting of accidents. As the SINAN is the official system for the notification of accidents by venomous animals in Brazil, it is imperative that its operation be reviewed and improved, given that effective measures to prevent accidents by venomous animals depend on a reliable database and the ability to accurately report the true conditions.
\end{abstract}

Keywords: Neglected tropical diseases. Epidemiologic surveillance. Public health. Underreporting.

Venomous animals. Bites and stings.

\section{INTRODUCTION}

Brazil is a country with more than $8,500 \mathrm{~km}$ of coastline and the largest freshwater system in the world, with a diverse aquatic fauna capable of causing lesions and/or intoxications in humans ${ }^{(1)(2)(3)}$. Risk activities for accidents caused by these animals typically include recreational and professional fishing, bathing in rivers and seas, and scuba diving or snorkeling ${ }^{(4)}$. In Brazil, several local and regional studies report injuries for aquatic animals $^{(5)(6)(7)(8)(9)(10)(11)(12)}$, but few papers that address and discuss the epidemiology of these injuries in the country are available ${ }^{(4)(13)}$.

Corresponding author: MSc. Guilherme Carneiro Reckziegel. Programa Nacional de Controle de Acidentes por Animais Peçonhentos/CGDT/MS. Setor Comercial Sul, Q.4, Bl A, Ed. Principal, Coordenação-Geral de Doenças Transmissíveis, Unidade VI do Ministério da Saúde, 70304-000 Brasília, Distrito Federal, Brasil.

Phone: 5561 3213-8248; Mobile: 5561 9115-1159

e-mail: guilherme.reckziegel@saude.gov.br; guilhermereckziegel@gmail.com Received 27 April 2015

Accepted 2 June 2015
The most common injuries by aquatic animals in Brazil are caused by sea urchins ${ }^{(14)}$, freshwater and marine fish, and cnidarians ${ }^{(4)}(13)$. Wounds by fish are typically caused by retro-opercular or dorsal spines, dorsal or caudal stingers and rays of fins, which are sharp and can be covered with a toxinproducing glandular tissue ${ }^{(4)(13)(15)}$. Envenoming by cnidarians (e.g., jellyfish, Portuguese man-of-war, anemones and corals) is caused by contact with the tentacles and even with the body of the animals, which have defensive cells bearing nematocysts. These organelles fire on contact with the human skin in a manner that is likened to a microscopic switchblade, injecting toxins with neurotoxic and cardiotoxic actions ${ }^{(4)(13)(15)}$. Traumatic wounds by sea urchins are very common, and the permanence of spines in the points of penetration favors secondary infections and the formation of foreign body granulomas ${ }^{(14)}$. Laboratory assays confirmed the presence of toxins in some parts of the black sea urchin (Echinometra lucunter $)^{(16)}$. However, clinical studies conducted in coastal zones of Southeastern Brazil have only found the existence of traumatic injuries and local manifestations in these occurrences ${ }^{(14)}$.

Deaths involving accidents by aquatic animals are rare, but they can occur in case of damage to vital organs ${ }^{(17)}$ or in severe cases of envenoming ${ }^{(18)}$. In Brazil, one death caused by myocardial perforation by the stinger of a marine catfish 
(Ariidae) ${ }^{(17)}$ and fatal cases of poisoning through ingestion of the pufferfish (Tetraodontidae) have been reported ${ }^{(19)}$. Notwithstanding, the injuries by aquatic animals can reach important clinical proportions. Envenomings by jellyfish and Portuguese man-of-war are characterized by typical linear lesions on the skin with variable extensions and can lead to severe cardiac and respiratory failure ${ }^{(20)}$.

The lesions caused by venomous fish are characterized by intense pain that is disproportional to the injury and possible local necrosis ${ }^{(21)}$. This profile is observed in many envenomings caused by venomous Brazilian fish, such as freshwater stingrays (Potamotrygonidae family), catfish (especially Ariidae and Pimelodidae families) ${ }^{(22)}$, toadfish (Batrachoididae family) ${ }^{(6)}$ and scorpionfish (Scorpaenidae family) (13) (23).

Although accident by venomous animals has been reported in Brazil for many years, the notification became compulsory only from $2010^{(24)(25)}$. To standardize these notifications and support epidemiological surveillance programs, the Brazilian Ministry of Health adopted the Information System for Notifiable Diseases [Sistema de Informação de Agravos de Notificação (SINAN)] as the official system for the notification of diseases and disorders of compulsory notification ${ }^{(25)}$. In the SINAN, envenomings/injuries by venomous animals are recorded in an electronic database called SINAN-Net. Since the version SINAN-Net was implemented in 2007, the field type of animal - fish was removed from the existing form, and accidents caused by aquatic animals were reported as accident type - other.

This change in reporting is a matter of concern given that the treatment of accidents with high morbidity, such as those caused by stingrays and other aquatic animals, without any specificity can lead to the perpetuation of neglected health problems with important socio-economic and epidemiological impacts $^{(8)(26)}$. This fact highlights the importance of evaluating injuries by aquatic animals in reporting systems, such as SINAN, to identify information gaps and suggest improvements. Thus, in the present study, we analyzed the accidents by aquatic animals registered in the SINAN database, described the epidemiological profile of these accidents in Brazil, and discussed possible inconsistencies in the analyzed records.

\section{METHODS}

We conducted a descriptive and retrospective epidemiological study on the injuries by aquatic animals recorded in the SINAN database between 2007 and 2013, emphasizing the envenomings by venomous species. For this analysis, the following variables presented in the Fields Notification/Investigation Sheet (FNI) of the SINAN form were used: age, sex, date, Federated Unit/ State of occurrence, occurrence area of the wound, elapsed time between the injury and the treatment, site and type of the wound, case classification, work-related accident and outcome.

The records were filtered from the accident type - other and divided into six groups of aquatic animals contained in the SINAN: jellyfish/Portuguese man-of-war, stingray, catfish, toadfish, sea urchin and other. Envenomings by stingrays were classified as occurring in a freshwater or marine environment according to the proximity or not of the municipality with the sea using the FNI location of occurrence of the accident. Accidents by stingrays that could not be classified as freshwater or marine were titled in a simplified form using names such as accident by stingray. The group other in the SINAN was composed of all accidents by aquatic animals that could not be classified in the six existing groups, such as: accident by fish, fish sting, marine fish, ictismo (i.e., an imprecise Brazilian term for accident by fish), Tilapia sp., piranha, trahira and moray eel. All records that could lead to errors in classification of the cases were excluded.

The data were organized using the softwares TabWin32 3.6b [Departamento de Informática do Sistema Único de Saúde (DATASUS), Brazil], EpiInfo 7.1.3.3 [Centers for Disease Control (CDC), USA] and Excel 2010 (Microsoft, USA). For the spatialization of the accidents, we used the TerraView 3.2.0 [Instituto Nacional de Pesquisas Espaciais (INPE), Brazil] software. For description and data analysis, we used raw data, simple frequency measures and arithmetic means.

\section{Ethical considerations}

The study complied with the ethical and legal requirements according to the Resolution 196/96 of the Brazilian National Health Council. However, as the study was based on secondary data and we did not have access to nominal information or any other information to promote identification, approval by an ethics committee was not necessary.

\section{RESULTS}

From 2007 to 2013, 4,118 injuries by aquatic animals in Brazil were registered in the SINAN (Table 1). Among these injuries, $88.7 \%(3,651)$ were caused by venomous aquatic animals, and $11.3 \%$ (467) were caused by poisonous and traumatic aquatic animals or unidentified taxa (Figure 1). Most accidents involved stingrays (69\%) and jellyfish/Portuguese man-of-war (13.1\%). Among the envenomings by stingrays, $91.6 \%(2,603)$ were caused by freshwater stingrays (Potamotrygonidae).

The male gender was the most (76.4\%) affected, with the exception of injuries caused by jellyfish/Portuguese man-of-war, which exhibited equal frequency between men and women. The most frequently affected individuals were 20 to 34 years old (32.2\%). Regarding jellyfish/Portuguese man-of-war accidents, most cases occurred in victims up to 19 years of age (68.8\%). This observation differs from accidents caused by stingrays (34.7\%), catfish $(29.6 \%)$ and sea urchins $(47.1 \%)$, which occurred more frequently in individuals 20 to 34 years old. Envenoming by toadfish more frequently occurred in individuals who were 35 to 49 years old (32.4\%) (Table 2).

Table 2 also shows that the location of the lesion was characteristic of the animal that caused the accident. Injuries caused by jellyfish/Portuguese man-of-war were distributed throughout the body, especially in extended areas, such as the thorax (21.5\%) and legs (20.2\%). Stingrays (83.6\%) and sea urchins $(52.9 \%)$ caused the most frequent injuries in the lower 
TABLE 1 - Accidents by aquatic animals registered in the SINAN. Brazil, 2007-2013.

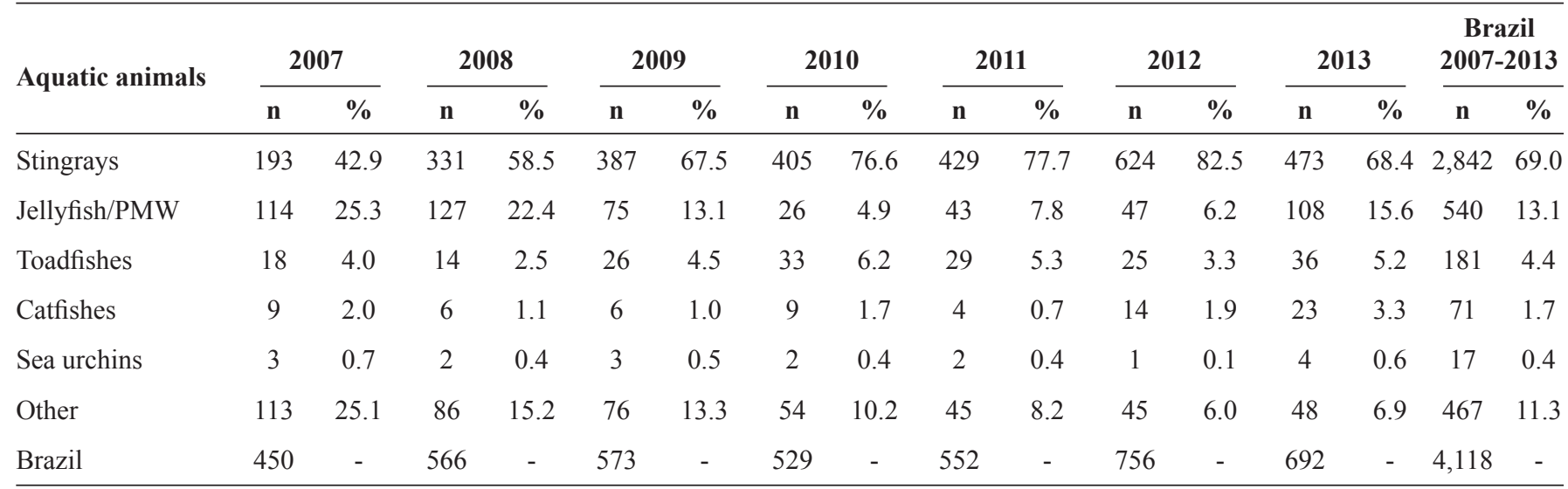

PMW: Portuguese man-of-war; SINAN: Sistema de Informação de Agravos de Notificação; SVS: Secretaria de Vigilância em Saúde; MS: Ministério de Saúde. Source: SINAN/SVS/MS.

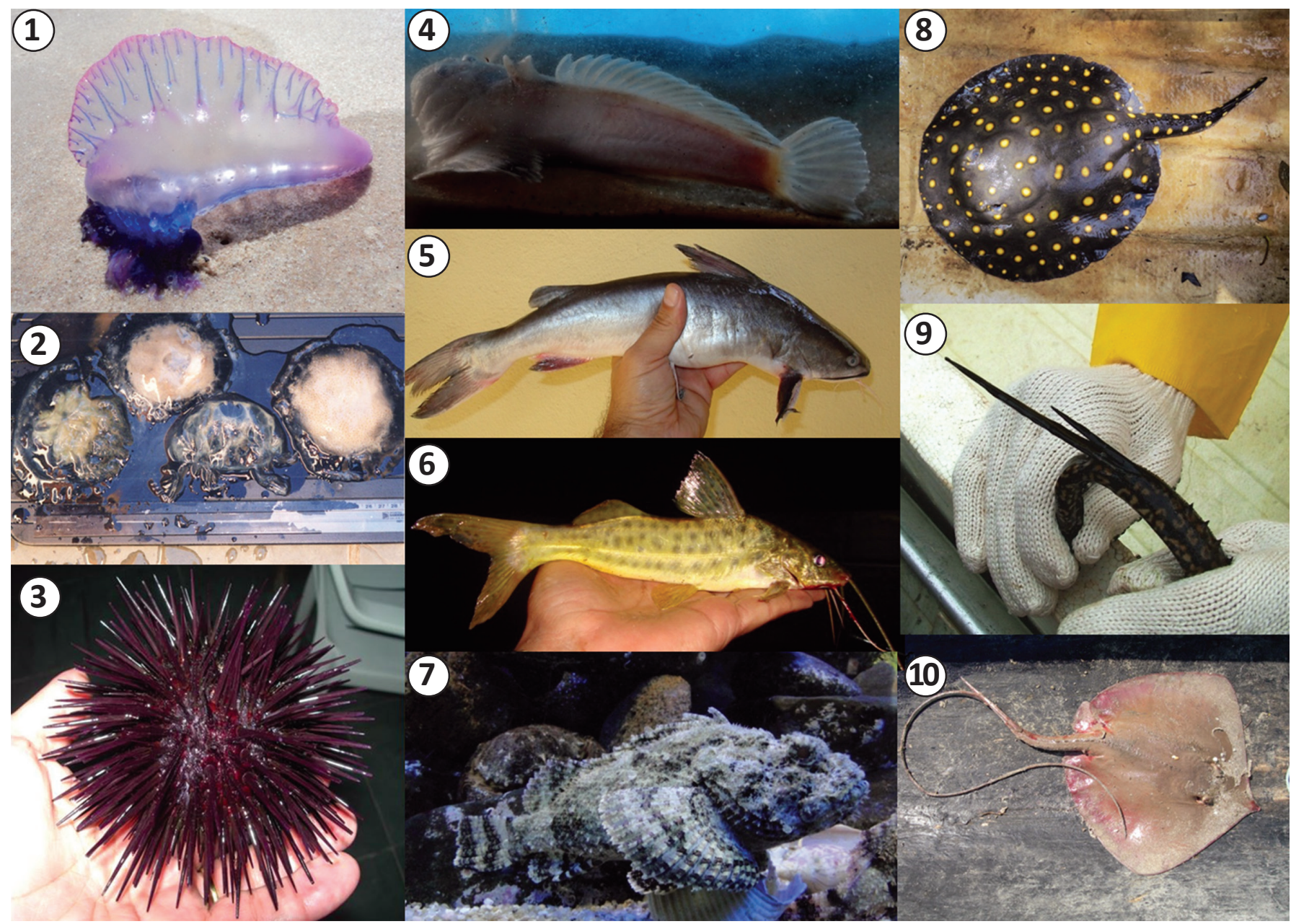

FIGURE 1 - Aquatic animals associated with injuries recorded by the SINAN from 2007 to 2013: 1) Portuguese man-of-war, Physalia physalis. 2) Jellyfish, Chrisaora lactea and Chiropsalmus quadrumanus. 3) Black sea urchin, Echinometra lucunter. 4) Toadfish, Thalassophryne nattereri. 5) Marine catfish, Genidens genidens. 6) Freshwater catfish, Pimelodus maculatus. 7) Scorpionfish, Scorpaena plumieri. 8) Freshwater stingray, Potamotrygon henlei. 9) Stingers of freshwater stingray. 10) Marine stingray, Dasyatis americana. (Images 1, 6 and 8 - Guilherme Carneiro Reckziegel; images 2 to 5, 7 and 10 - Vidal Haddad Junior; image 9 - Domingos Garrone Neto). SINAN: Sistema de Informação de Agravos de Notificação. 
TABLE 2 - Epidemiological characteristics of the accidents by aquatic animals registered in the SINAN. Brazil, $2007-2013$.

\begin{tabular}{|c|c|c|c|c|c|c|c|c|c|c|c|c|c|c|}
\hline \multirow[t]{2}{*}{ Aquatic animals } & \multicolumn{2}{|c|}{$\begin{array}{c}\text { Jellyfishes/PMW } \\
\text { N=540 }\end{array}$} & \multicolumn{2}{|c|}{$\begin{array}{c}\text { Stingrays } \\
\mathrm{N}=\mathbf{2 , 8 4 2}\end{array}$} & \multicolumn{2}{|c|}{$\begin{array}{c}\text { Catfishes } \\
\quad \mathrm{N}=71\end{array}$} & \multicolumn{2}{|c|}{$\begin{array}{c}\text { Toadfishes } \\
\mathbf{N}=181\end{array}$} & \multicolumn{2}{|c|}{$\begin{array}{c}\text { Sea Urchins } \\
\qquad \mathbf{N}=\mathbf{1 7}\end{array}$} & \multicolumn{2}{|c|}{$\begin{array}{l}\text { Other } \\
\mathrm{N}=467\end{array}$} & \multicolumn{2}{|c|}{$\begin{array}{c}\text { Total } \\
\mathrm{N}=4,118\end{array}$} \\
\hline & n & $\%$ & n & $\%$ & $\mathbf{n}$ & $\%$ & $\mathbf{n}$ & $\%$ & $\mathbf{n}$ & $\%$ & $\mathbf{n}$ & $\%$ & $\mathbf{n}$ & $\%$ \\
\hline \multicolumn{15}{|l|}{ Gender } \\
\hline male & 270 & 50.0 & 2,308 & 81.2 & 58 & 81.7 & 140 & 76.9 & 12 & 70.6 & 358 & 76.8 & 3,146 & 76.4 \\
\hline female & 270 & 50.0 & 534 & 18.8 & 13 & 18.3 & 41 & 22.5 & 5 & 29.4 & 109 & 23.4 & 972 & 23.6 \\
\hline \multicolumn{15}{|l|}{ Age (years) } \\
\hline$\leq 9$ & 193 & 35.7 & 158 & 5.6 & 1 & 1.4 & 5 & 2.7 & 2 & 11.8 & 32 & 6.9 & 391 & 9.5 \\
\hline 10 to 19 & 179 & 33.1 & 649 & 22.8 & 18 & 25.4 & 28 & 15.4 & 5 & 29.4 & 120 & 25.8 & 999 & 24.3 \\
\hline 20 to 34 & 108 & 20.0 & 986 & 34.7 & 21 & 29.6 & 55 & 30.2 & 8 & 47.1 & 149 & 32.0 & 1,327 & 32.2 \\
\hline \multicolumn{15}{|l|}{ Injury site } \\
\hline forearm & 30 & 5.6 & 14 & 0.5 & 2 & 2.8 & 1 & 0.5 & 1 & 5.9 & 5 & 1.1 & 53 & 1.3 \\
\hline hand/finger & 70 & 13.0 & 82 & 2.9 & 28 & 39.4 & 82 & 45.1 & 2 & 11.8 & 143 & 30.7 & 407 & 9.9 \\
\hline chest/abdomen & 116 & 21.5 & 6 & 0.2 & 0 & 0.0 & 1 & 0.5 & 1 & 5.9 & 6 & 1.3 & 130 & 3.2 \\
\hline leg & 109 & 20.2 & 231 & 8.1 & 2 & 2.8 & 3 & 1.6 & 0 & 0.0 & 23 & 4.9 & 368 & 8.9 \\
\hline foot/toe & 37 & 6.9 & 2,375 & 83.6 & 29 & 40.8 & 72 & 39.6 & 9 & 52.9 & 263 & 56.4 & 2,785 & 67.6 \\
\hline other* & 153 & 28.3 & 55 & 1.9 & 5 & 7.0 & 3 & 1.6 & 2 & 11.8 & 13 & 2.8 & 231 & 5.6 \\
\hline ignored/not answered & 25 & 4.6 & 79 & 2.8 & 5 & 7.0 & 19 & 10.4 & 2 & 11.8 & 14 & 3.0 & 144 & 3.5 \\
\hline 12 to 24 & 12 & 2.2 & 110 & 3.9 & 4 & 5.6 & 20 & 11.0 & 2 & 11.8 & 42 & 9.0 & 190 & 4.6 \\
\hline$>24$ & 23 & 4.3 & 265 & 9.3 & 18 & 25.4 & 27 & 14.8 & 4 & 23.5 & 61 & 13.1 & 398 & 9.7 \\
\hline ignored/not answered & 69 & 12.8 & 352 & 12.4 & 10 & 14.1 & 45 & 24.7 & 3 & 17.6 & 54 & 11.6 & 533 & 12.9 \\
\hline
\end{tabular}

SINAN: Sistema de Informação de Agravos de Notificação; PMW: Portuguese man-of-war. *head, thigh and arm. Source: SINAN.

limbs (especially in the feet), and catfish and toadfish caused injuries mostly on the feet $(40.8 \%$ and $39.6 \%)$ and hands (39.4\% and $45.1 \%)$. The time between the accident and clinical treatment varied. Victims of accidents by jellyfish/Portuguese man-of-war, stingray and catfish sought medical care mostly within three hours post-accident $(78.4 \%, 61.7 \%$ and $45.3 \%$, respectively). However, records of treatment after 24 hours were observed in accidents by catfish $(25.4 \%)$, sea urchins $(23.5 \%)$ and toadfish $(13.1 \%)$.

The North region was responsible for the most accidents registered in the SINAN (66.2\%), with important emphasis on accidents by stingrays $(88.4 \%)$. Among these, $92.2 \%(2,317)$ of accidents were caused by freshwater stingrays. The South region recorded the second highest number of accidents $(15.7 \%)$, which were primarily caused by jellyfish/Portuguese man-of-war (83.7\%). With $12.5 \%$ of the records, the Northeast region was notable with almost all accidents caused by toadfish (95.6\%) (Table 3).

Figure 2 shows that among the Brazilian states, Pará reported most of the accidents $(897 ; 21.8 \%)$ with $86.4 \%$ (775) of injuries caused by stingrays, followed by Tocantins $(837 ; 20.3 \%)$ with $95.1 \%$ (796) of accidents caused by freshwater stingrays, Paraná $(513 ; 12.5 \%)$; with $72.4 \%$ (372) of accidents caused by jellyfish/Portuguese man-of-war, and Amazonas (428; 10.4\%) with $96.3 \%$ (412) of accidents caused by freshwater stingrays. Records of accidents caused by toadfish were more frequent 
TABLE 3 - Distribution of accidents caused by aquatic animals according to the type of animal and macro-region. Brazil, $2007-2013$.

\begin{tabular}{|c|c|c|c|c|c|c|c|c|c|c|c|c|c|c|}
\hline \multirow{2}{*}{ Macro-Regions } & \multicolumn{2}{|c|}{ Jellyfishes/PMW* } & \multicolumn{2}{|c|}{ Stingrays } & \multicolumn{2}{|c|}{ Catfishes } & \multicolumn{2}{|c|}{ Toadfishes } & \multicolumn{2}{|c|}{ Sea urchins } & \multicolumn{2}{|c|}{ Other } & \multicolumn{2}{|c|}{ Brazil } \\
\hline & $\mathbf{n}$ & $\%$ & $\mathbf{n}$ & $\%$ & $\mathbf{n}$ & $\%$ & $\mathbf{n}$ & $\%$ & $\mathrm{n}$ & $\%$ & $\mathbf{n}$ & $\%$ & $\mathbf{n}$ & $\%$ \\
\hline North & 0 & 0.0 & 2,511 & 88.4 & 6 & 8.5 & 6 & 3.3 & 1 & 5.9 & 204 & 43.5 & 2,728 & 66.2 \\
\hline Northeastern & 83 & 15.4 & 85 & 3.0 & 27 & 38.0 & 174 & 95.6 & 6 & 35.3 & 141 & 30.1 & 516 & 12.5 \\
\hline Southeastern & 5 & 0.9 & 27 & 1.0 & 1 & 1.4 & 2 & 1.1 & 3 & 17.6 & 33 & 7.0 & 71 & 1.7 \\
\hline Brazil & 540 & - & 2,842 & - & 71 & - & 181 & - & 17 & - & 467 & - & 4,118 & - \\
\hline
\end{tabular}

PMW: Portuguese man-of-war; SINAN: Sistema de Informação de Agravos de Notificação. Source: SINAN.

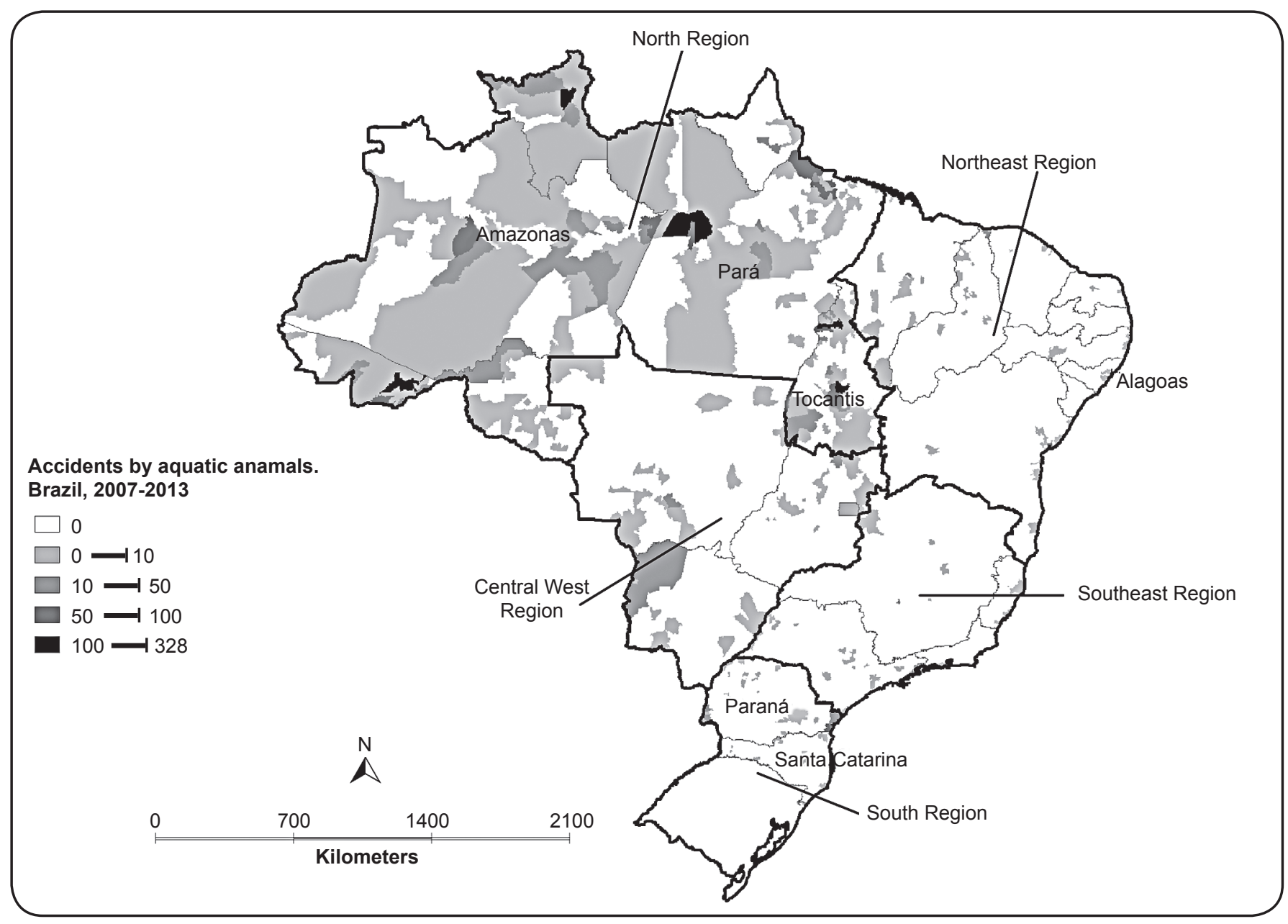

FIGURE 2 - Distribution of accidents by aquatic animals in Brazil. 2007-2013. SINAN: Sistema de Informação de Agravos de Notificação; Source: SINAN. 
in the State of Alagoas (113; 62.4\%). Accidents caused by catfish were most common in the State of Paraná (28; 39.4\%), and accidents by sea urchins were most common in the State of Santa Catarina ( $7 ; 41.2 \%)$. In addition, other less frequent cases were observed over the Brazilian states: envenoming by lionfish (one record in São Paulo City); accidents by scorpionfish (one record in Santa Catarina, one in Pernambuco, three in Bahia, and one in Paraná); and intoxications by pufferfish (one record in Santa Catarina, one in Paraná, and one in the Rio Grande do Norte).

On a microscale, the municipalities in Brazil with the highest number of records were: I) Santarém/Pará (329) with 99.7\% (328) of accidents caused by freshwater stingrays; II) Palmas/Tocantins (322) with $96.9 \%$ (312) of accidents caused by freshwater stingrays; III) Pontal do Paraná/Paraná (258) with $99.6 \%$ (257) of accidents caused by jellyfish/Portuguese man-of-war; IV) Boa Vista/Roraima (148) with 95.3\% (141) of accidents caused by freshwater stingrays; V) Maceió/Alagoas (132) with $65.9 \%$ (87) of accidents caused by toadfish; VI) Araguaína/Tocantins (127) with 96.9\% (123) of accidents caused by freshwater stingrays, and VII) Rio Branco/Acre (108) with $98.1 \%$ (106) of accidents caused by freshwater stingrays.

\section{DISCUSSION}

The accidents by aquatic animals registered in the SINAN/ Brazil increased to greater than 50\% from 2007 to 2013, particularly the cases of accidents by stingrays and jellyfish/ Portuguese man-of-war, which accounted for $82 \%$ of cases.

Envenomings caused by marine and freshwater stingrays are relatively common in Brazilian fishing communities ${ }^{(27)}$. However, accidents caused by stingrays are typically unreported due to their occurrence in remote areas where access to health services is limited ${ }^{(8)}$. Thus, despite an apparent concern by the health services in reporting cases, the data presented here possibly represent just a small fraction of all occurrences. Local and regional surveys demonstrated that accidents involving stingrays still occur silently and are closely related to beach seasons, school vacations and traditional fishing activities $^{(21)(26)(27)(28)}$. Accidents caused by stingrays are also commonly accompanied by popular treatments and delays in the search for medical attention, which favors the occurrence of disabling injuries and promotes the lack of reporting by the SINAN ${ }^{(8)(26)}$.

Garrone Neto et al. ${ }^{(26)}$ and Garrone Neto \& Haddad $\mathrm{Jr}^{(8)}$ confirm this fact in studies of victims of stingray injuries who did not seek medical care and cases where even under medical care the accidents were not recorded in the SINAN. Additionally, Rosseto et al. ${ }^{(29)}$ reports 38 cases of seabather's eruption, a dermatitis caused by the planulae larvae of the scyphomedusae Linuche unguiculata. This study reports that the number of victims was likely underestimated because many of them did not go to hospitals or clinics for medical treatment, and proper notification was consequently not made. Other studies also presented an important difference between the number of notifications in the SINAN and other reporting systems, raising the possibility of underreporting. Here, underreporting is noted as the existence of victims who did not seek clinical care and as the positive difference between the frequencies of accidents recorded in other sources and accidents recorded in the SINAN in the same location and year ${ }^{(30)}$.

For accidents by jellyfish/Portuguese man-of-war, the occurrence of underreporting in the SINAN is also recognized. However, in this case, the increase in the number of records in the SINAN appears to be more related to the large outbreaks that occurred in the South and Southeastern regions in recent years, rather than with a permanent action for monitoring and notification of accidents by cnidarians. Marques et al. ${ }^{(31)}$ reported approximately 20,000 accidents by jellyfish in the State of Paraná in the summer of 2011 to 2012 and presented several nonexclusive hypotheses to explain the occurrence of such a number of cases. One of these ideas involved an efficient method of data collected by firemen (lifeguards) and the health department during this season, which may indicate that the real number of accidents may not have been accurately reported in previous years with a high possibility of underreporting in the SINAN ${ }^{(31)}$.

Regarding accidents by sea urchins, Haddad $\mathrm{Jr}^{(13)(32)}$ states that injuries by these animals are very common and represent over $50 \%$ of the occurrences with aquatic animals observed in the emergency services of the Southeastern coast of Brazil. This finding is in contrast to our findings. Perhaps the low severity of the injuries, which are typically treated with the simple extraction of spines, discourages the search for medical care and justifies such a difference between the records.

In relation to other types of accidents, such as those caused by toadfish and catfish, we expect a similar situation regarding underreporting. Accidents with toadfish are recognized as frequent and an important public health issue in the Northeastern and North shores of Brazil ${ }^{(6)}$. Injuries and envenomings by catfish are also important in different Brazilian regions, both in freshwater and marine environments. However, as with the majority of the accidents investigated in this study, an important delay in the search for clinical care was noted by some victims, particularly regarding accidents caused by catfish and toadfish. The mild severity of these envenoming prompts the victims to use popular home treatments for the injuries, which delays or limits the demand for medical care ${ }^{(10)(26)}$.

The severity of the accident, which is often evaluated by the victim based on the lesion appearance and/or intensity of pain, causes an increased demand for clinical care. Thus, this characteristic can justify the low frequency of accidents by toadfish and catfish as well as the high (69\%) frequency of accidents by stingrays observed in this study. Injuries by others fishes, such as the scorpionfish and lionfish, and intoxications by pufferfish were considered uncommon in the SINAN database. However, due to the potential of severe cases of pain and intoxication (including fatal cases), occurrences involving these fish should be further investigated given that several species belonging to the families Scorpaenidae and Tetraodontidae are found in Brazil.

In addition to the problem of underreporting, the identification of accidents by aquatic animals in the SINAN as accident typeother reduced the quality of the data analyzed. The professionals responsible for filling this FNI in the SINAN form address 
this process of identification via a variety of diverse methods, thus resulting in several cases being not reported or exclusively classified as accident by aquatic animal. This fact undermines the actual determination of the problem in the country and complicates the planning of preventive actions given that the accident characteristics are particular to each group of animals. Furthermore, the FNI field local of occurrence of the accident was insufficient for the classification of the total accidents by stingrays as occurred in rivers or coastal areas. This limitation is another important failure of the SINAN due to the high morbidity and marked seasonality of accidents by stingrays in the Central West and North regions, where these accidents could be easily avoided through information programs and collective protection measures in areas and with high-risk groups (e.g., bathers, riverside communities and marine/freshwater fishermen).

The envenomings/injuries caused by aquatic animals were reported in the SINAN for all regions of Brazil. Accidents by stingrays, especially those occurring in the North region, were the most frequent occurrence registered in the SINAN possibly due to the increased morbidity of these events. Injuries by cnidarians were important in the South region, following jellyfish and Portuguese man-of-war outbreaks during the austral summer. Accidents with sea urchins in the analyzed data proved to be underestimated, since they represent over $50 \%$ of all accidents recorded by the health services in Southeast coast during the austral summer. Although a comparison of different databases has not been performed, the data presented in this study indicate an important underreporting of accidents compared with local and regional surveys.

In contrast to the reporting systems designed for snakebites and spiders and scorpions stings, the study of injuries caused by aquatic animals in Brazil has always been relegated to a second plan and neglected by the agencies responsible for the knowledge, control and prevention of diseases involving venomous animals. Due to a gap in the epidemiology of accidents caused by aquatic animals in Brazil, the limited information available in the literature is the result of cross-sectional studies or active searches of cases or research in medical files, with the appropriate restrictions inherent to the collection of secondary data. Thus, given that the SINAN is the official system for the notification of accidents caused by venomous animals in Brazil, it is imperative that the system is improved and that its use be encouraged, given that effective measures to prevent and control accidents by venomous animals depend on reliable data and the ability to accurately report the problem.

\section{CONFLICT OF INTEREST}

The authors declare that there is no conflict of interest.

\section{REFERENCES}

1. Silva CCP, Zannin M, Rodrigues DS, Santos CR, Correia IA, Haddad Jr V. Clinical and epidemiological study of 27 poisonings caused by ingesting puffer fish (Tetrodontidae) in the states of
Santa Catarina and Bahia, Brazil. Rev Inst Med trop Sao Paulo 2010; 52:47-50

2. Barreiros JP, Haddad Jr V. Bite by Moray Eel. J Venom Anim Toxins incl Trop Dis 2008; 14:541-545.

3. Haddad Jr V, Sazima I. Piranhas attacks in Southeast of Brazil: epidemiology, natural history and clinical treatment with description of a bite outbreak. Wilderness Environ Med 2003; 14:249-254

4. Haddad Jr V. Animais Aquáticos Potencialmente Perigosos do Brasil: guia médico e biológico. São Paulo: Editora Roca; 2007.

5. Haddad Jr V, Silveira FL, Cardoso JLC, Morandini AC. A report of 49 cases of cnidarian envenoming from southeastern Brazilian coastal waters. Toxicon 2002; 40:1445-1450.

6. Haddad Jr V, Pardal PPO, Cardoso JLC, Martins IA. The venomous toadfish Thalassophryne nattereri (niquim or miquim): report of 43 injuries provoked in fishermen of Salinópolis (Pará State) and Aracaju (Sergipe State), Brazil. Rev Inst Med Trop Sao Paulo 2003; 45:221-223.

7. Neves RF, Amaral FD, Steiner AQ. Levantamento de registros dos acidentes com cnidários em algumas praias do litoral de Pernambuco (Brasil). Ciênc Saúde Colet 2007; 12:231-237.

8. Garrone Neto D, Haddad Jr V. Arraias em rios da Região Sudeste do Brasil: locais de ocorrência e impactos sobre a população. Rev Soc Bras Med Trop 2010; 43:82-88.

9. Haddad Jr V, Silveira FL, Migotto AE. Skin lesions in envenoming by cnidarians (Portuguese man-of-war and jellyfish): etiology and severity of accidents on the Brazilian coast. Rev Inst Med Trop Sao Paulo 2010; 52:47-50.

10. Silva GC, Sabino J, Alho CJR, Nunes VLB, Haddad Jr V. Injuries and envenoming by aquatic animals in fishermen of Coxim and Corumbá municipalities, State of Mato Grosso do Sul, Brazil: identification of the causative agents, clinical aspects and first aid measures. Rev Soc Bras Med Trop 2010; 43:486-490.

11. Resgalla Jr C, Rosseto AL, Haddad Jr V. Report of an outbreak of stings caused by Olindias sambaquiensis Muller, 1861 (Cnidaria: hydrozoa) in Southern Brazil. Braz J Oceanogr 2011; 59:391-396.

12. Haddad Jr V, Virga S, Bechara A, Silveira FL, Morandini AC. An outbreak of Portuguese man-of-war (Physalia physalis Linnaeus, 1758) envenoming in Southeastern Brazil. Rev Soc Bras Med Trop 2013; 46:641-644.

13. Haddad Jr V. Animais aquáticos de importância médica no Brasil. Rev Soc Bras Med Trop 2003; 36:591-597.

14. Haddad Jr V. Observation of initial clinical manifestations and repercussions from the treatment of 314 human injuries caused by black sea urchins (Echinometra lucunter) on the southeastern Brazilian coast. Rev Soc Bras Med Trop 2012; 45:390-392.

15. Ministério da Saúde, Fundação Nacional de Saúde. Manual de diagnóstico e tratamento de acidentes por animais peçonhentos. $2^{\text {nd }}$ ed. Brasília: Fundação Nacional de Saúde; 2001.

16. Sciani JM, Antoniazzi MM, Neves AC, Pimenta DC. Cathepsin $\mathrm{B} / \mathrm{X}$ is secreted by Echinometra lucunter sea urchin spines, a structure rich in granular cells and toxins. J Venom Anim Toxins Incl Trop Dis 2013; 19:33.

17. Haddad Jr V, Souza RA, Auerbach P. Marine Catfish Sting Causing Fatal Heart Perforation in a Fisherman. Wilderness Environ Med 2008; 19:114-118.

18. Lumley J, Williamson JA, Fenner PJ, Burnett JW, Colquhoun DM. Fatal envenomation by Chironex fleckeri, the north Australian box jellyfish: the continuing search for lethal mechanisms. Med J Aust 1988; 148:527-534.

19. Santana Neto PL, Aquino ECM, Silva JA, Amorim MLP, Oliveira Jr AE, Haddad Jr V. Envenenamento fatal por baiacu 
(Tetraodontidae): relato de um caso em criança. Rev Soc Bras Med Trop 2010; 43:92-94.

20. Haddad Jr V. Environmental dermatology: skin manifestations of injuries caused by invertebrate aquatic animals. An Bras Dermatol 2013; 88:496-506.

21. Pardal PPO. Ictismo por arraia. In: Cardoso JLC, França FOS, Wen FH, Málaque CMS, Haddad Jr V, editors. Animais Peçonhentos no Brasil: Biologia, Clínica e Terapêutica dos Acidentes. São Paulo: Sarvier; 2003. p. 279-285.

22. Haddad Jr V, Lastória JC. Acidentes por mandijubas (mandisamarelos): aspectos clínicos e terapêuticos. Diagn Tratamento 2005; 10:122-123.

23. Haddad Jr V, Martins IA, Makyama HM. Injuries caused by scorpion fishes (Scorpaena plumier Bloch, 1789 and Scorpaena brasiliensis Cuvier, 1829) in the Southwestern Atlantic Ocean (Brazilian coast): epidemiologic, clinic and therapeutic aspects of 23 stings in humans. Toxicon 2003; 42:79-83.

24. Ministério da Saúde. Portaria $\mathrm{n}^{0}$ 2.472, de 31 de agosto de 2010. Define as terminologias adotadas em legislação nacional, conforme disposto no Regulamento Sanitário Internacional 2005 (RSI 2005), a relação de doenças, agravos e eventos em saúde pública de notificação compulsória em todo o território nacional e estabelecer fluxo, critérios, responsabilidades e atribuições aos profissionais e serviços de saúde. Diário Oficial da União, Poder Executivo, Brasília, 1 set 2010. Seção 1. p. 50 (Portaria revogada pela Portaria $\mathrm{n}^{\circ} 104$, de 25 de janeiro de 2011).

25. Ministério da Saúde. Portaria n 1.271 , de 06 de junho de 2014. Define a Lista Nacional de Notificação Compulsória de doenças, agravos e eventos de saúde pública nos serviços de saúde públicos e privados em todo o território nacional, nos termos do anexo, e dá outras providências. Diário Oficial da União, Poder Executivo, Brasília, 09 jun 2014. Seção 1. p. 67 (Esta portaria revogou a Portaria $\mathrm{n}^{\mathrm{o}}$ 104, de 25 de janeiro de 2011).

26. Garrone Neto D, Cordeiro RC, Haddad Jr V. Acidentes do trabalho em pescadores artesanais da região do Médio Rio Araguaia, Tocantins, Brasil. Cad Saude Publica 2005; 21:795-803.

27. Garrone Neto D, Haddad Jr V. Acidentes por raias. In: Cardoso JLC, França FOS, Wen FH, Málaque CMS, Haddad Jr V, editors. Animais Peçonhentos no Brasil: Biologia, Clínica e Terapêutica dos Acidentes. $2^{\text {nd }}$ ed. São Paulo: Sarvier; 2009. p. 295-313.

28. Haddad Jr V, Garrone Neto D, Paula Neto JB, Marques FPL, Barbaro KC. Freshwater stingrays: study of epidemiologic, clinic and therapeutic aspects based on 84 envenomings in humans and some enzymatic activities of the venom. Toxicon 2004; 43: 287-294.

29. Rossetto AL, Dellatorre G, da Silveira FL, Haddad Jr V. Seabather's eruption: a clinical and epidemiological study of 38 cases in Santa Catarina State, Brazil. Rev Inst Med Trop Sao Paulo 2009; 51:169-175.

30. Fiszon JT, Bochner R. Subnotificação de acidentes por animais peçonhentos registrados pelo SINAN no Estado do Rio de Janeiro no período de 2001 a 2005. Rev Bras Epidemiol 2008; 11:114-127.

31. Marques AC, Haddad Jr V, Rodrigo L, Marques-da-Silva E, Morandini AC. Jellyfish (Chrysaoralactea, Cnidaria, Semaeostomeae) aggregations in southern Brazil and consequences of stings in humans. Lat Am J Aquat Res 2014; 42:1194-1199.

32. Haddad Jr V. Atlas de animais aquáticos perigosos do Brasil guia médico de diagnóstico e tratamento de acidentes. São Paulo: Editora Roca; 2000. 